\title{
Variability of Fusarium oxysporum f. sp. lycopersici from different altitudes in East Java, Indonesia
}

\author{
Henik Sukorini ${ }^{1}$, Erfan Dani Septia ${ }^{2 *}$, and Netnapis Khewkhom ${ }^{3}$ \\ ${ }^{1}$ Department of Agrotechnology, Faculty of Agriculture and Animal Science, \\ University of Muhammadiyah Malang, Jl. Raya Tlogomas no 246 Malang 65145, \\ East Java, Indonesia \\ ${ }^{2}$ The Center of Biotechnology Development, University of Muhammadiyah Malang \\ ${ }^{3}$ Department of Plant Pathology, Faculty of Agriculture, Kasetsart University, 50 Thanon \\ Ngamwongwan, Lat Yao, Chatuchak, Bangkok 10900, Thailand
}

\begin{abstract}
Fusarium wilt disease attacks the tomato plants, and Solanaceae plants with losses can reach $90 \%$. Thus, this disease was tough to control. The morphology and pathogenicity variation caused failure disease control. Both variations could be affected by the altitude of the planting site. Therefore, it also required special handling of management as well. The specific objectives of this study to investigate the Fusarium isolate from different altitude response of physical properties (acid-base $\mathrm{pH}$, low-high temperature, and fungicides of other active ingredients) and growth rate of Fusarium. All Fusarium sp. were isolated from the leaves, soil, roots, and stem of infected tomato plants. Before a series of tests were carried out, all of the isolates were tested for pathogenicity, then tested for the influence of abiotic factors. This study obtained four isolates from high altitude, four isolates from medium altitude, and five lowland isolates. In morphological observations, there were striking differences in colony color and growth rate among isolates on several media and pathogenicity tests. Each isolate had different pathogenicity, although from the same location but other parts of the plant. Knowing the characteristic morphology and Fusarium sp. response of the three areas can be used as references in controlling.
\end{abstract}

Keywords: Isolates, pathogenicity variation, solanaceae, wilt disease.

\section{Introduction}

Fusarium oxysporum f. sp. lycopersici (Sacc.) W.C. Snyder and H.N. Hans. is a cosmopolitan species that can be found in all soil types in the world [1]. Fusarium is an economically very important species because it causes wilt and root rot disease in some plants [2]. Distinguishing Fusarium pathogens is not easy [3]. The identification of Fusarium is based primarily on differences in the shape and size of macro and microconidia, presence or absence of chlamydospores, and appearance of colonies pigmentation, growth rates on agar mediums [4]. However, some forma species and races

\footnotetext{
*Corresponding author: erfandani@umm.ac.id
} 
of F. oxysporum was tough to distinguish in this way [5]. A report reveals that there are cultural and morphological variations in Fusarium oxysporum f. sp. psidii isolate and $F$. solani when tested in vitro on growth and physiological parameters [6].

Some Fusarium species have been reported to grow and produce spores in $\mathrm{pH} 5.0$ to pH 6.0 [7]. Arcía et al. [8] reported that Fusarium spp., F. oxysporum and F. solani require $\mathrm{pH} 4.5$ and 6.0, while $F$. graminearum and $F$. equiseti at $\mathrm{pH} 3.5$ and $\mathrm{pH} 6.5$. That $\mathrm{pH} 5.5$ to $\mathrm{pH} 7.0$ was the optimum $\mathrm{pH}$ for growth and sporulation of $F$. solani [9]. Besides, Hsuan et al. [10] tested Gibberella fujikuroi at various temperatures, suitable temperatures for growth and sporulation was a temperature of $30^{\circ} \mathrm{C}$ followed by $25^{\circ} \mathrm{C}, 20^{\circ} \mathrm{C}$, and $35^{\circ} \mathrm{C}$. Tyagi 2014 [11] studied the effect of temperature on growth and sporulation of $F$. oxysporum $\mathrm{f}$. sp. lines.

This research was a follow-up from previous research controlling Fusarium sp., a wilt disease on tomato plants. From the previous research result, Fusarium oxysporum isolates of the same low altitudes site plant, but different plant parts had the same character of shape and size of spore, but growth characteristics were different, as well as pathogenicity and virulence. So that the response to bio-pesticide from bio-diesel waste of Jatropha seeds also different levels of success. Other studies have also revealed that in the presence of a specific form of the Fusarium sp., it causes difficulties in controlling it [12]. Amandeep 2015 [13] studied the variability of isolate $F$. oxysporum f. sp. ciceri. As a result, it is difficult to control the disease [14]. So, it needs to be revealed more about the difference of isolated characters from many altitudes.

\section{Material and methods}

\subsection{Pathogen isolates}

Fusarium sp. isolates obtained from the isolation of the three regions that have different altitudes, at low (140 $\mathrm{m}$ to $200 \mathrm{~m}$ above sea level, $\mathrm{m}$ asl), medium (678 $\mathrm{m}$ asl to $700 \mathrm{~m}$ asl), and high altitudes (1 $100 \mathrm{~m}$ asl to $1200 \mathrm{~m}$ asl). Isolation was done by culturing $0.5 \mathrm{~cm}$ of the infected plant part (root, stem, leaves) and $1 \mathrm{~g}$ of soil from around the root on Potato Dextrose Agar media, then purifying for testing [15].

\subsection{Pathogenicity test}

The pathogenicity test was done by deep root method. Plants that have been sown for $30 \mathrm{~d}$ were removed and cleaned from the soil. The suspense was made from $7 \mathrm{~d}$ old isolate. The population density of the suspense was $1 \times 10^{8}$. The root ends were cut as many as ten pieces, then depth in each inoculum's suspense for $20 \mathrm{~min}$. Then, the inoculated plants were transferred into polybags containing sterile soil and sand at a ratio of $1: 1$, then incubated for 2 wk to 4 wk at $27^{\circ} \mathrm{C}$ to $30^{\circ} \mathrm{C}$. Isolates that could show disease symptoms were considered to have the ability to cause disease. To ensure the result of the pathogenicity test, it was done twice [16].

\subsection{Characterization of growth}

Fusarium diameter and sporulation were observed by culturing the isolate on Potato Dextrose agar (PDA) medium, Czapek's Dox Agar medium (CDA), Cooke's Rose Bengal Agar medium (CRBA) and Oatmeal Agar medium (OA) [17]. Each Petri dish was filled with $20 \mathrm{~mL}$ of media then $5 \mathrm{~mm}$ diameter of Fusarium isolate was placed in the middle of the Petri dish, then incubated at a temperature of $28^{\circ} \mathrm{C} \pm 2^{\circ} \mathrm{C}$ for $9 \mathrm{~d}$. Measurement of 
growth diameter and sporulation was done every $3 \mathrm{~d}$ after incubation. Total spore was calculated by cutting $5 \mathrm{~mm}$ the edge of isolate culture, then added $10 \mathrm{~mL}$ sterile water, shaken, then observed with haemocytometer. Moreover, growth characterizations such as colony thickness and colony color were observed. The growth rate of isolate was also studied by using liquid medium Potato Dextrose Broth (PDB) medium, Czapek's Dox Broth medium (CDB), Cooke's Rose Bengal Broth medium (CRBB), and Oatmeal Broth medium (OB). Isolates were grown in $100 \mathrm{~mL}$ of liquid medium and stored for seven days at a temperature of $28^{\circ} \mathrm{C} \pm 2{ }^{\circ} \mathrm{C}$. The mycelium was then filtered with Whatman filter paper number 42 , dried at $60^{\circ} \mathrm{C}$., then measured.

\subsection{In vitro isolates resistance test to temperature, $\mathrm{pH}$, and fungicide}

The influence of temperature on growth and sporulation of Fusarium sp isolates was observed by growing $5 \mathrm{~mm}$ colonies diameter in the middle of Potato Dextrose agar (PDA) medium, then grew at $\left(10,16,22,28,34\right.$, and 40) ${ }^{\circ} \mathrm{C} \pm 1{ }^{\circ} \mathrm{C}$. Growth diameter and sporulation were observed at $7 \mathrm{~d}$ after inoculation [9]. The growth rate on $\mathrm{pH}(5,6,7$ and 8) was observed after $7 \mathrm{~d}$ cultured on PDB, but resistance to Fungicides was observed by measuring the colony diameter on PDA at $7 \mathrm{~d}$ after inoculation.

\section{Result and discussions}

There were thirteen isolates from three different altitudes, four from high, four from a medium, and five isolates from low altitudes. In the lowlands, two isolates from the leaves were obtained, which looked morphologically different.

\subsection{Pathogenicity test}

In pathogenicity test, results indicated that most of $F$. oxysporum were pathogenic. These isolates caused wilt symptoms on at least one plant on the tomato plant, stem cross-section also done to ensure the pathogenicity. The result of pathogenicity was presented in Table 1.

Table 1. Pathogenicity test of Fusarium sp isolates from three different altitudes

\begin{tabular}{llll}
\hline Altitude & Sample Source & 1 st test & 2nd test \\
\hline High & Soil & + & - \\
& Root & + & - \\
& Stem & + & + \\
\multirow{5}{*}{ Medium } & Leaves & - & + \\
& Soil & + & + \\
& Root & - & + \\
& Stem & + & + \\
& Leaves & + & + \\
& Soil & + & + \\
& Root & + & + \\
& Stem & + & + \\
& Leaves 1 & + & + \\
& Leaves 2 & + & + \\
\hline
\end{tabular}

+ Appeared symptom, No symptom appeared 
Pathogenicity tests was done twice. The distance between the first and second tests is $2 \mathrm{wk}$ in the greenhouse. Several isolates were not consistent to show wilt even symptoms on leaves. Isolates that always appeared symptom were isolates from the lowland.

\subsection{Characterization of growth}

Four solid media (OA, CRBA, PDA, and CDA) were used for cultural studies. The colony color varies from white to purplish white, but all of the Fusarium isolates were white on CDA medium, and the thickness of the colony also varies greatly (Table 2).

Table 2. The thickness and colony color of isolates from three different altitudes on OA, CRBA, PDA, and CDA medium

\begin{tabular}{|c|c|c|c|c|c|c|c|c|c|}
\hline \multirow[b]{3}{*}{ Altitude } & \multirow{3}{*}{$\begin{array}{l}\text { Sample } \\
\text { Source }\end{array}$} & \multicolumn{4}{|c|}{ Thickness } & \multicolumn{4}{|c|}{ Colony color } \\
\hline & & $\mathrm{O}$ & CRB & $\mathrm{PD}$ & $\mathrm{CD}$ & & & & \\
\hline & & A & A & A & A & $\mathrm{OA}$ & CRBA & PDA & $\mathrm{CDA}$ \\
\hline \multirow[t]{4}{*}{ High } & Soil & ++ & + & ++ & ++ & $\begin{array}{l}\text { White } \\
\text { purplish }\end{array}$ & $\begin{array}{l}\text { white } \\
\text { purplish }\end{array}$ & white & white \\
\hline & Root & + & + & ++ & ++ & white & white & white & white \\
\hline & Stem & $\begin{array}{l}+ \\
++\end{array}$ & + & +++ & + & white & white & white & white \\
\hline & Leaves & + & + & +++ & +++ & white & white & white & white \\
\hline \multirow[t]{4}{*}{ Medium } & Soil & + & + & ++ & ++ & $\begin{array}{l}\text { White } \\
\text { purplish }\end{array}$ & $\begin{array}{l}\text { White } \\
\text { purplish }\end{array}$ & $\begin{array}{l}\text { White } \\
\text { purplish }\end{array}$ & white \\
\hline & Root & + & + & ++ & ++ & white & white & white & white \\
\hline & Stem & $\begin{array}{l}+ \\
++\end{array}$ & + & + & + & white & white & white & white \\
\hline & Leaves & + & +++ & +++ & +++ & white & $\begin{array}{l}\text { white } \\
\text { purplish }\end{array}$ & $\begin{array}{l}\text { white } \\
\text { purplish }\end{array}$ & white \\
\hline \multirow[t]{5}{*}{ Low } & Soil & ++ & + & ++ & ++ & purple & white & white & white \\
\hline & Root & $\begin{array}{l}++ \\
++\end{array}$ & ++ & ++ & ++ & white & white & white & white \\
\hline & Stem & $\begin{array}{l}+ \\
++\end{array}$ & ++ & + & +++ & white & white & white & white \\
\hline & Leaves 1 & + & +++ & +++ & ++ & white & white & white & white \\
\hline & Leaves 2 & $\begin{array}{l}++ \\
+ \\
\end{array}$ & $\begin{array}{l}+++ \\
+ \\
\end{array}$ & $\begin{array}{l}+++ \\
+ \\
\end{array}$ & $\begin{array}{l}+++ \\
+ \\
\end{array}$ & white & white & white & white \\
\hline
\end{tabular}

Knowing another morphological character, colony diameter, sporulation, and growth rate of each isolate was culture on four different media. All isolates had the same growth in all four media, except for isolates from high and low altitudes, respectively, isolates from leaves from the highlands and isolates from stems from lowlands (Figure 1). While for sporulation, isolates originating from the lowlands, namely isolates from roots and soil, can produce spores that were much stronger than other isolates. In isolate No. 1 originating from leaves in the lowlands, sporulation in CRBA media was much lower than that of other media (Figure 3). The growth rate, observed by growing Fusarium sp. grown on four types of liquid media, then filtered, dried, then weighed. The results of the weighing showed that the isolates originating from the plain medium could grow faster than the isolates from the high and lowlands (Figure 3). 


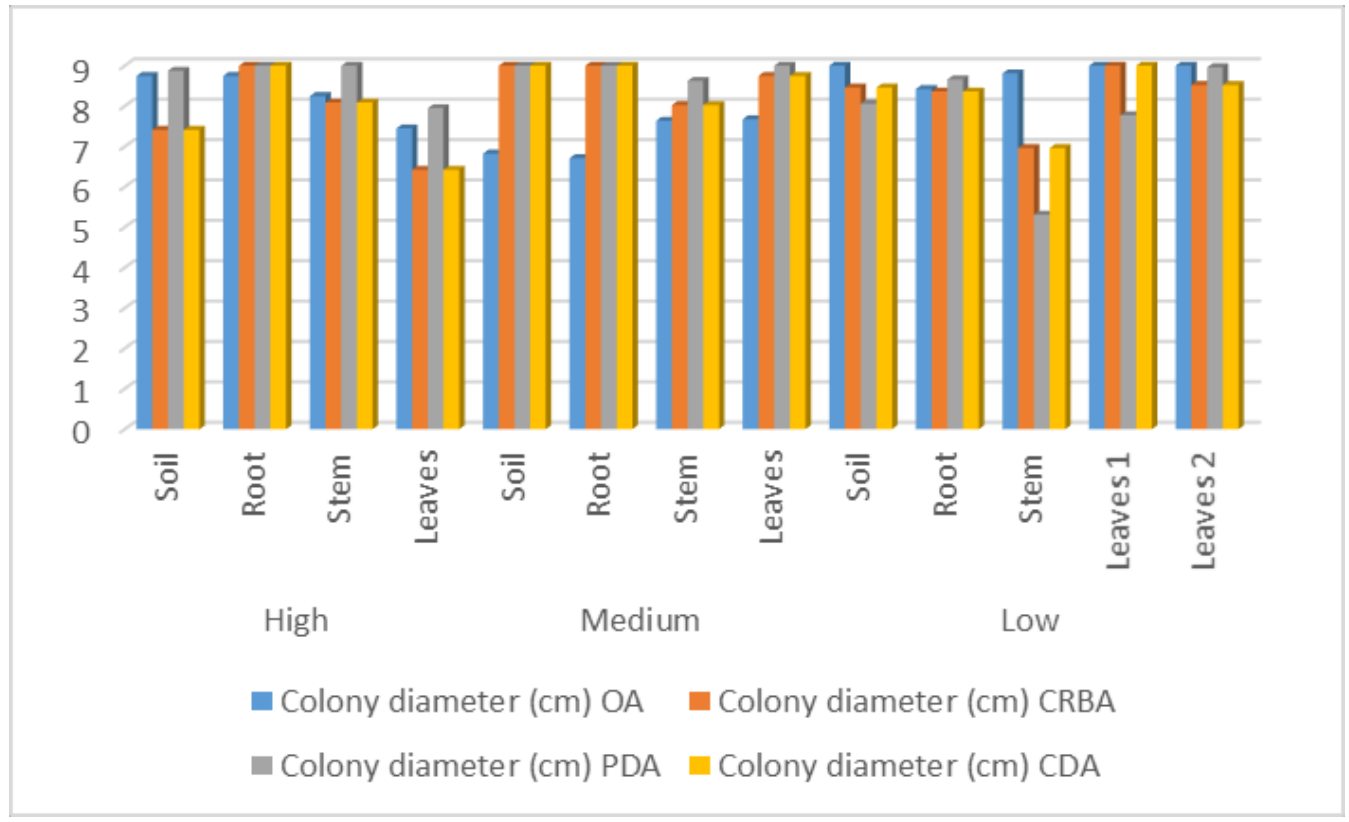

Fig. 1. Colony diameter (cm) of Fusarium sp. isolates on OA, CRBA, PDA, and CDA medium, $7 \mathrm{~d}$ after inoculation

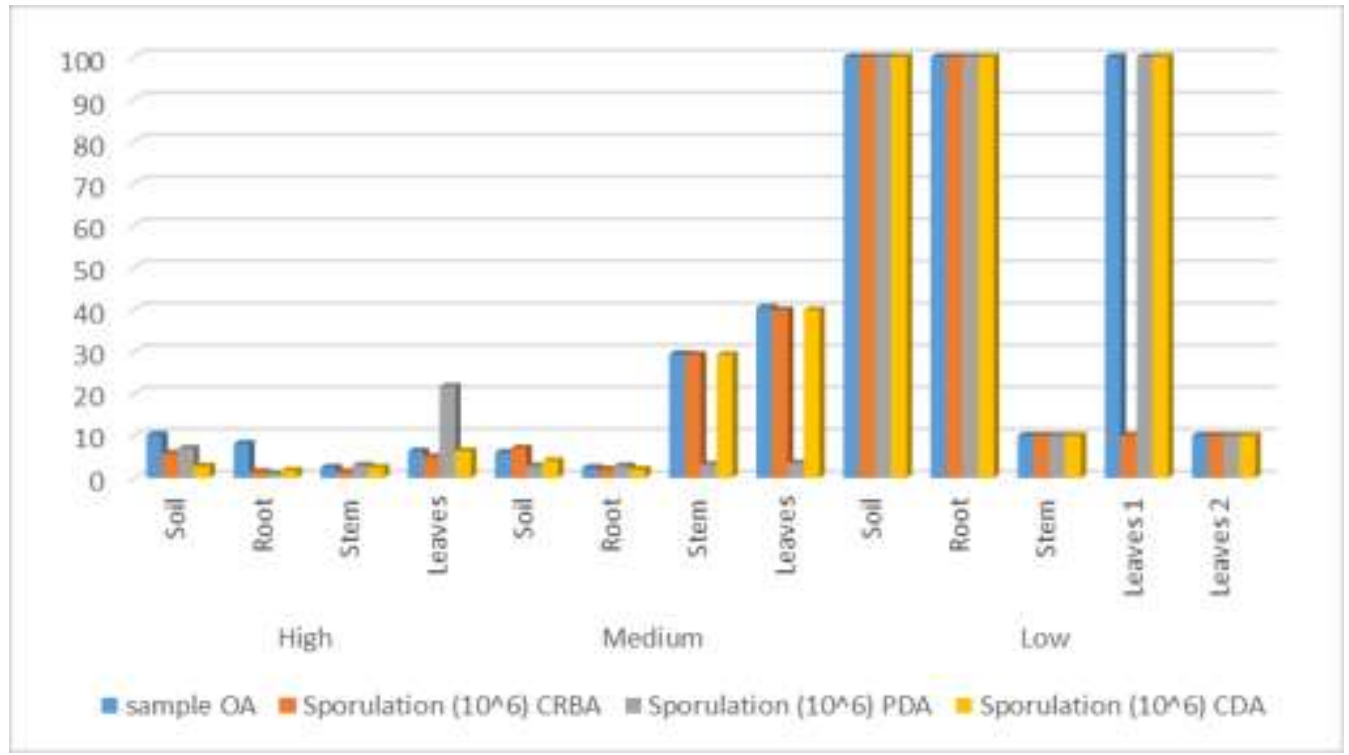

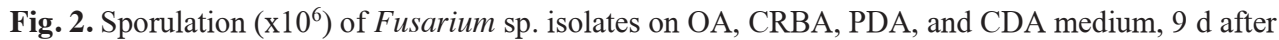
inoculation 


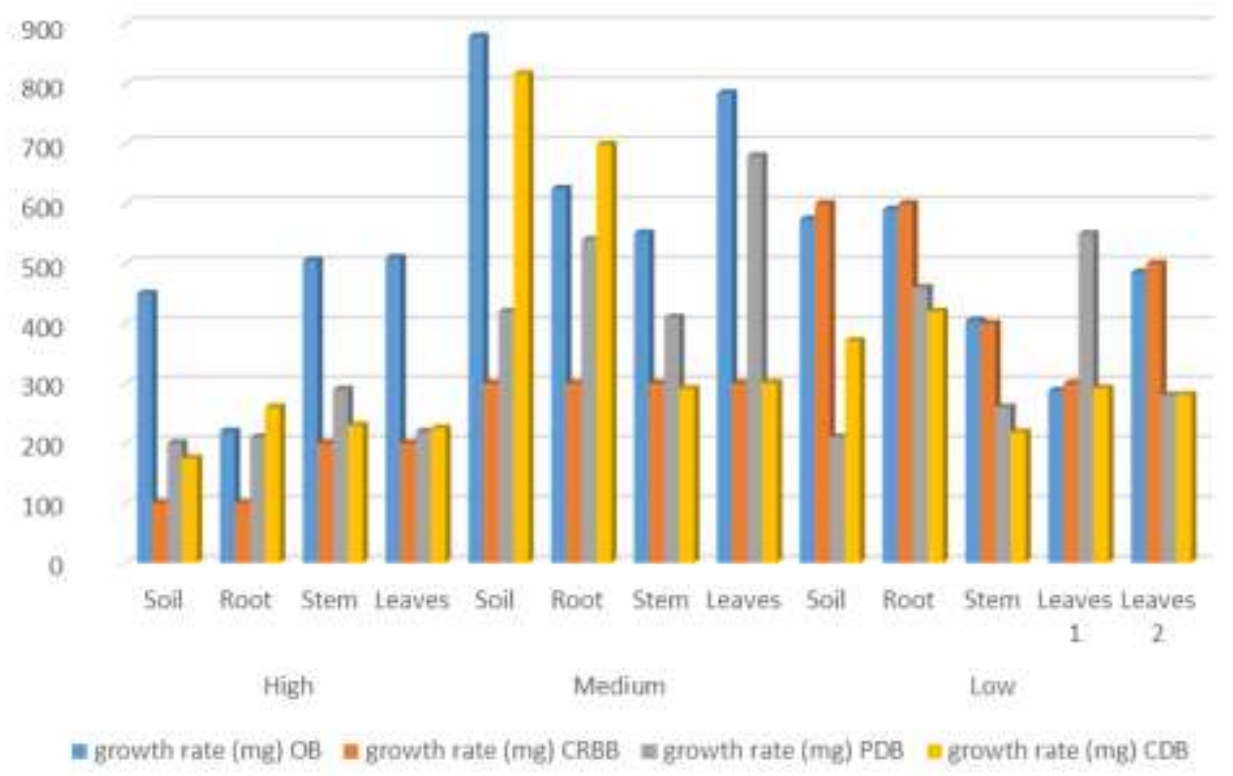

Fig. 3. Growth rate (mg) of Fusarium sp. isolates on OB, CRBB, PDB, and CDB liquid media, $7 \mathrm{~d}$ after inoculation

\subsection{Effect of Growth temperature, $\mathrm{pH}$, fungicide on Fusarium sp growth}

The growth pattern of all isolates from three heights was the same, all isolates continued to increase to a temperature of $22{ }^{\circ} \mathrm{C}$, but then the growth of all isolates decreased to $34{ }^{\circ} \mathrm{C}$, except for isolates from the lowlands, which were leaves (no 2), roots, and stems (Figure 4). The sporulation trend was exciting because only a few isolates increased the number of spores as the temperature rises. Isolates from high land were isolated from roots and soil respectively, isolates from temperate plains which originated from roots and soil, and isolates from lowland which isolates from the soil, starting at $16^{\circ} \mathrm{C}$ the number of spores produced increased continuously to $34^{\circ} \mathrm{C}$, whereas other isolates despite an increase but not too significant (Figure 5).

Testing the sensitivity of isolates to $\mathrm{pH}$ was carried out at $\mathrm{pH} 5$ to $\mathrm{pH} .7$. The test results showed that all isolates grew optimum at $\mathrm{pH}$ seven and would decrease if the $\mathrm{pH}$ of the media was raised to $\mathrm{pH} 8$ (Figure 6). this result was slightly different from the last research [1]. Most of the Fusarium oxysporum isolates favored the $\mathrm{pH}$ of 7.5, slightly alkaline conditions. Mezzomo et al. [9] found that mycelia of $F$. oxysporum, which grew within the range of $\mathrm{pH} 2$ to $\mathrm{pH} 12, \mathrm{pH} 0$ to $\mathrm{pH}$, was the most suitable for the growth of all Fusarium species, while a highly acidic medium was unsuitable for the sporulation of all Fusarium species. 


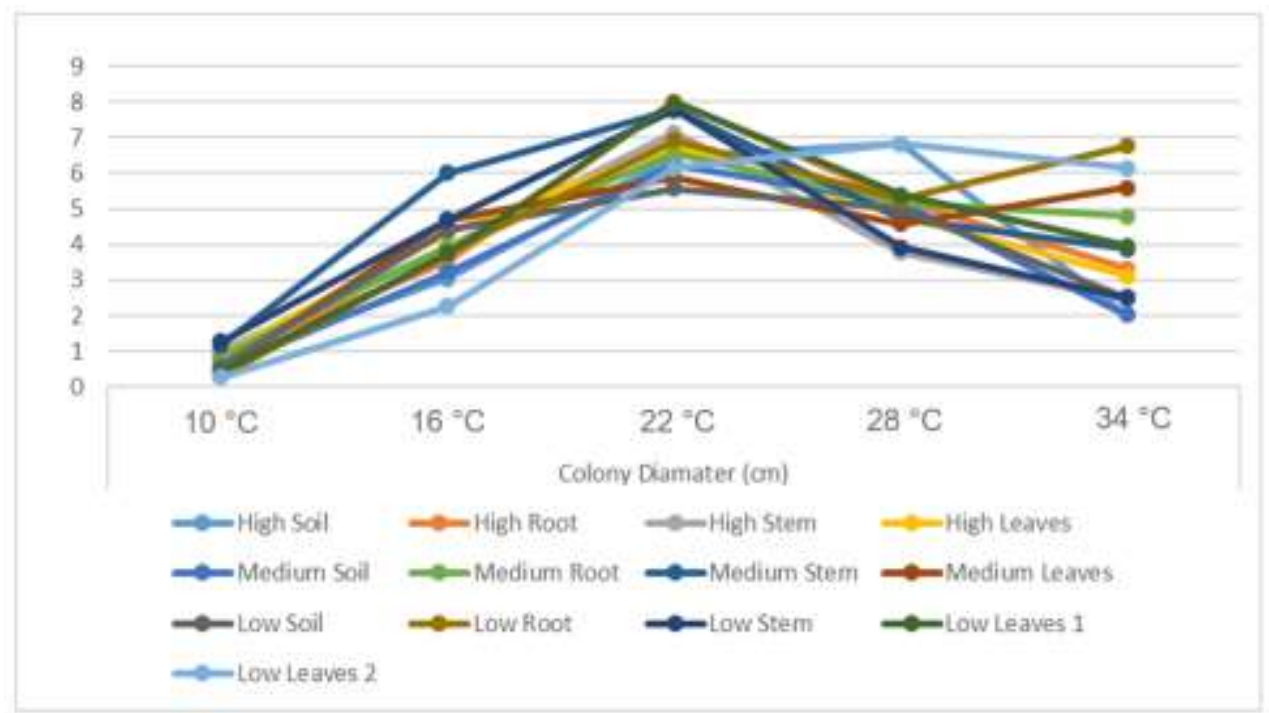

Fig. 4. Colony diameter of Fusarium sp. from three different altitudes that have grown on $(10,16,22$, 28 , and 34$)^{\circ} \mathrm{C}$

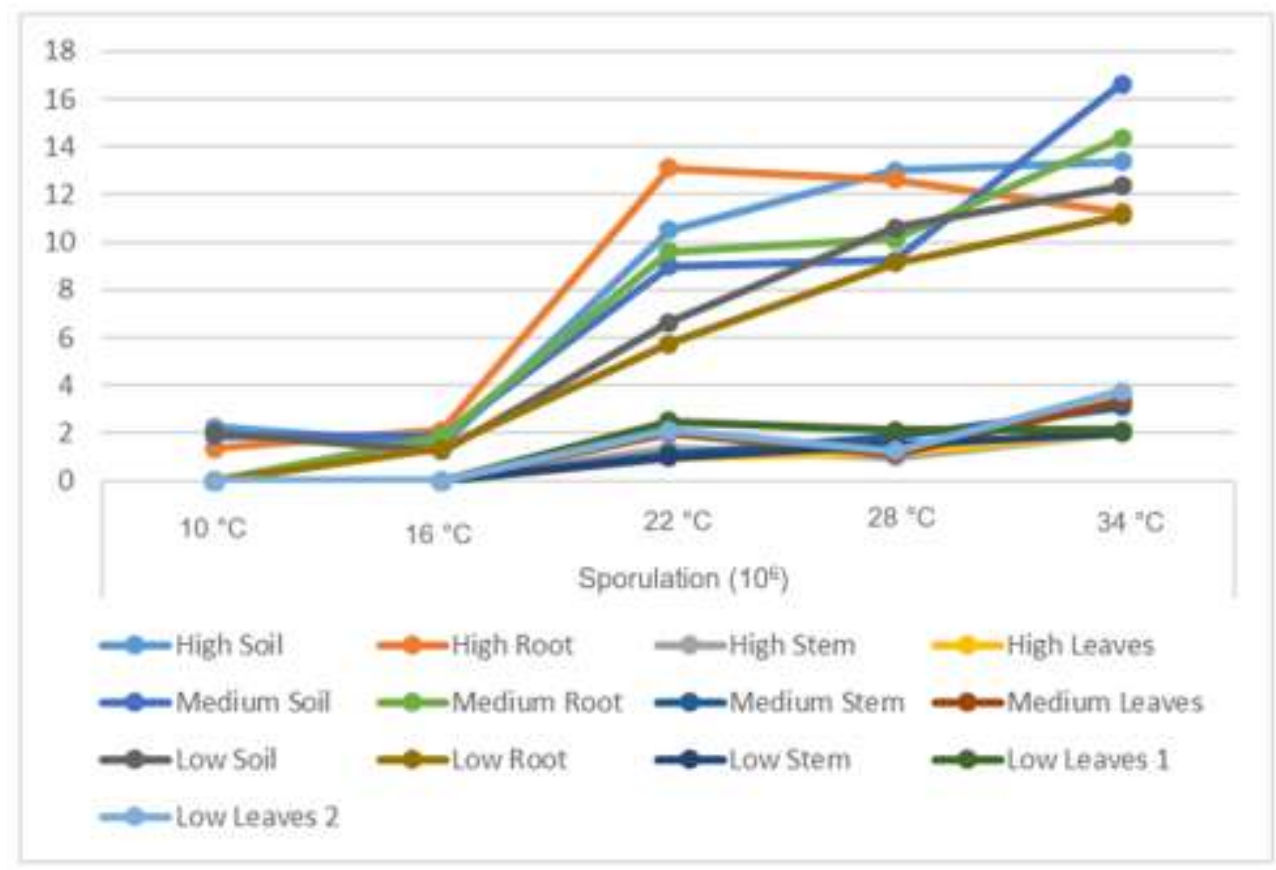

Fig. 5. Sporulation of Fusarium sp. from three different altitudes that grown on (10, 16, 22, 28, and 34) ${ }^{\circ} \mathrm{C}$ 


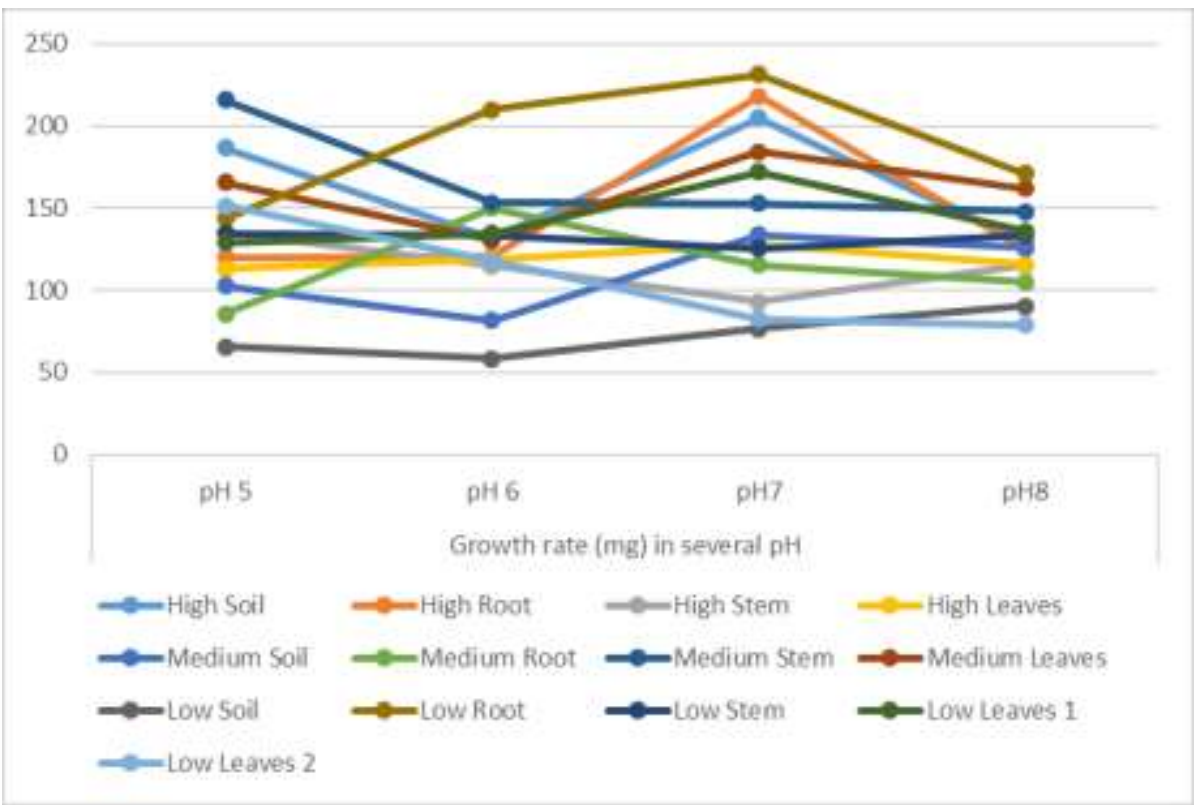

Fig. 6. Colony diameter of Fusarium sp. from three different altitudes that grown on $(10,16,22,28$, and 34$)^{\circ} \mathrm{C}$

Testing the sensitivity of the active ingredients of fungicides is done by adding fungicides commonly used by farmers at recommended dosages. The results showed that the fungicide, which had an active ingredient of Mancozeb $64 \%+$ Metalaxyl $8 \%$, inhibited the growth of Fusarium sp. by $60 \%$ (Figure 7).

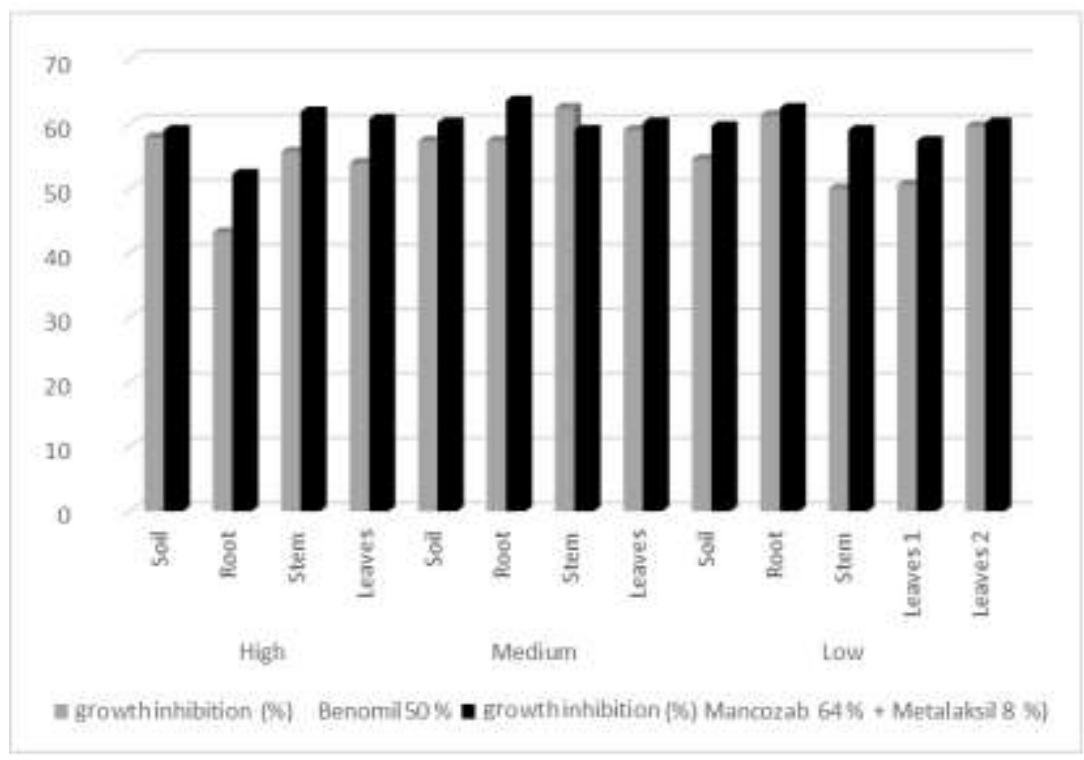

Fig. 7. Inhibition percentage of Fungicide to Fusarium growth 


\section{Conclusions}

The character of the isolates varied in several media, i.e., the character of growth and color of the isolate. The optimum temperature for growth and sporulation is at $22{ }^{\circ} \mathrm{C}$, while the optimum $\mathrm{pH}$ was 7 . Fungicide with Mancozeb $64 \%+$ Metalaxyl $8 \%$ only could inhibit not more than $60 \%$.

\section{References}

1. M. Joshi, R. Srivastava, A.K. Sharma, A. Prakash, J. Appl. Nat. Sci., 5:108117(2013). https://doi.org/10.31018/jans.v5i1.290

2. S. Srivastava, C. Kadooka, J.Y. Uchida, Microbiol. Res., 207,2017:188-195(2018). https://doi.org/10.1016/j.micres.2017.12.002

3. S.N. Rampersad, Pathogens, 9,5:340(2020). https://doi.org/10.3390/pathogens 9050340

4. A. Robles-Carrión, M. Leiva-Mora, L. Herrera-Isla, A. Sánchez-Rodríguez, R. TorresGutiérrez, Rev. Protección Veg., 31,3:184-193(2016). http://scielo.sld.cu/scielo.php?script=sci abstract\&pid $=$ S1010-27522016000300005

5. V. Edel-Hermann, C. Lecomte, Phytopathology, 109,4:512-530(2019). https://doi.org/10.1094/PHYTO-08-18-0320-RVW

6. G. Sharma, R. R. Pandey, J. Yeast Fungal Res., 1,8:157-164(2010). https://doi.org/10.5897/JYFR.9000029

7. M.Z. Hussain, M. Rahman, M.N. Islam, M. Latif, M. Bashar, Bangladesh J. Bot, 41,1:49-54(2012). https://doi.org/10.3329/bjb.v41i1.11082

8. J. Adame-García, R. Rodríguez-Guerra, L.G. Iglesias-Andreu, J.M. Ramos-Prado, M. Luna-Rodríguez, Bot. Sci., 93,3:669-678(2015). https://doi.org/10.17129/botsci.142

9. R. Mezzomo, J.M. Rolim, T. Poletto, M.B. De Oliveira, M. Lazarotto, M.F.B. Muniz, Sci. Agrar., 19,1:14-19(2018). https://doi.org/10.5380/rsa.v19i1.55844 d

10. H. M. Hsuan, B. Salleh, L. Zakaria, Int. J. Mol. Sci., 12,10:6722-6732(2011). https://doi.org/10.3390/ijms12106722

11. S. Tyagi, R. Paudel, Int. J. Basic Appl. Biol., 2,1:103-106(2014). https://www.krishisanskriti.org/ijbab.html

12. I.M. Singha, Y. Kakoty, B.G. Unni, M.C. Kalita, J. Das, A. Naglot, et al., World J. Microbiol. Biotechnol., 27,11:2583-2589(2011). https://doi.org/10.1007/s11274-011$\underline{0730-6}$

13. K. Amandeep, K.S. Vineet, S. Asmita, K. Jaspal, S. Gursahib, K. Pardeep, African J. Microbiol. Res., 9,15:1089-1097(2015). https://doi.org/10.5897/ajmr2014.7267

14. K. Sasaki, K. Nakahara, S. Tanaka, M. Shigyo, S. I. Ito, Phytopathology, 105,4:525532(2015). https://doi.org/10.1094/PHYTO-06-14-0164-R

15. M. Ignjatov, D. Milošević, Z. Nikolić, J. Gvozdanović-varga, Pesticidi i fitomedicina, 27,1:25-31(2012). https://doi.org/10.2298/PIF1201025I

16. C. Srinivas, D.N., Devi, K.N., Murthy, C.D., Mohan, T.R., Lakshmeesha, B. Singh, Saudi J. Biol. Sci., 26,7:1315-1324(2019). https://doi.org/10.1016/j.sjbs.2019.06.002

17. S.P. Gautam, P.S. Bundela, A.K. Pandey, M.K. Awasthi, S. Sarsaiya, Ann. Environ. Sci.,5:23-34(2011). http://openjournals.neu.edu/aes/journal/article/view/v5art4 